\title{
Effect of ginger powder incorporation on physicochemical and organoleptic characteristics of biscuits
}

\author{
Tusneem Kausar*, Muhammad Asjad and Muhammad Nadeem \\ Institute of Food Science and Nutrition, University of Sargodha, Sargodha 40100-Pakistan \\ *Corresponding author's email: tusneemft@yahoo.com \\ Citation \\ Tusneem Kausar, Muhammad Asjad and Muhammad Nadeem. Effect of ginger powder incorporation on \\ physicochemical and organoleptic characteristics of biscuits. Pure and Applied Biology. Vol. 6, Issue 4, pp1244-
} 1250. http://dx.doi.org/10.19045/bspab.2017.600132

Received: 19/05/2017 Revised: 21/09/2017

Accepted: 23/09/2017

Online First: 26/09/2017

\section{Abstract}

Present investigations were performed to examine the effect of incorporation of ginger powder on the physicochemical and organoleptic characteristics of the biscuits. For this, fresh ginger was dried, ground in powder and added in wheat flour at $0,2.5,5,7.5$ and 10\% concentration for preparation of the biscuits. It was found that ginger powder incorporation increased thickness, hardness and fracturability as compared to the biscuits without ginger powder. The moisture, protein, ash and crude fiber contents increased while nitrogen free extract decreased significantly $(\mathrm{p}<0.05)$ with progressive substitution of ginger powder. There was no significant difference noticed for fat content. Organoleptic properties in terms of color, flavor, crispiness, texture and overall acceptability were only acceptable at minimum level of ginger powder.

Keywords: Ginger; Biscuits; Physical analysis; Chemical characteristics; Sensory properties

\section{Introduction}

In Pakistan, cereals are the primary source of protein and calorie. Among cereals, wheat (Triticum aestivam) is the most important food crop ranked first for human consumption. It is the staple food for millions of people and its contribution in daily diet is $68-75 \%$ in Pakistan [1]. Cereals including wheat provide the highest calories, proteins, fibre, some vitamins and minerals of human requirements in most countries of the world [2]. Wheat flour is normally used for the production of bakery products such as cakes, buns, breads and biscuits. Bakery products are gaining popularity due to increasing trend of urbanization and increase in the number of working women. Among bakery products, biscuits are the most favorite because of their long shelf life, low cost, availability in different forms and good nutritional value. Bakery products are sometimes used as a vehicle for incorporation of different nutritionally rich ingredients [3-9]. Foods based on cereals are most attracted by people in countries where wheat is used as basic diet. Innovation in technology has permitted bakers to develop their products with functional foods that improve function, taste and the texture.

In all over the world functional foods based on vegetable source are gaining reputation due to their beneficial application. Phytochemistry related to health claims is the major reason for the utilization of plant sources [10]. Huge variety of native plants is present in Pakistan and many of them 
have a strong flavor and health related benefits. Ginger (Zingiber officinale) is one of them also known as Adrak. In the Middle East and Asia, it is widely used as a medicinal plant as it helps in digestion, treatment of gout, eye sight and joints. The early Chinese used ginger as remedy against nausea, morning sickness, indigestion and heartburn. They believed that ginger is a natural internal cleaning and purifying agent. Ginger has very useful medicinal values, antioxidant properties as well as some antimicrobial properties. These can be employed in food industry to boost up the quality and shelf-life of processed foods [11]. The present research is an effort to incorporate the ginger in the form of powder in biscuits and then to evaluate them for physical, chemical and sensory characteristics.

\section{Materials and methods}

Wheat flour, fresh ginger roots (Zingiber officinale) and other ingredients needed for biscuits preparation were purchased from local market. Ginger powder was obtained by washing the roots, removing non-edible parts and drying in an oven at $40 \pm 2^{\circ} \mathrm{C}$. A grinder mill was used to obtain ginger powder and packed in an air tight container and stored.

\section{Biscuit Preparation}

The biscuits were formulated according to the method No. 10-50D as described in AACC [12]. Wheat flour was replaced with ginger powder at $0,2.5,5,7.5$ and $10 \%$ concentration for various treatments.

\section{Physical analysis of ginger powder incorporated biscuits}

The AACC [12] methods were adopted in order to determine the diameter, thickness and spread factor of biscuits. For measurement of diameter (mm), six biscuits were placed edge to edge, their total width was measured and average diameter was determined by taking the mean value. Average thickness $(\mathrm{mm})$ of the biscuits was measured by placing six biscuits one on top of another and measuring their height and taking average. Spread factor was obtained by dividing the diameter with thickness. Color of biscuits was determined with the help of colorimeter (Color Test-II Neuhaus Neotec). It was first calibrated by using standard (54 CTn for dark and 151 CTn for light) and the color of biscuits was determined by placing the biscuits under the photocell. Texture of biscuits was measured using TA-XT-plus texture analyzer which gave the measurement of the hardness and resistance of the biscuits to bend or snap.

Chemical analysis of ginger powder incorporated biscuits

Chemical composition of biscuits including moisture, crude protein, crude fat, ash, crude fibre and NFE were analyzed according to the method described in AOAC [13]. The energy values were calculated theoretically using the conversion factors of 4.0, 4.0 and $9.0 \mathrm{kcal} / \mathrm{g}$ for protein, carbohydrates and fats, respectively, according to the method described by [14].

Sensory evaluation of ginger powder incorporated biscuits

Biscuits were evaluated by a panel of judges according to the method described by [15]. The parameters studied were color, taste, flavor, texture and overall acceptability. The score cards for the evaluation of the biscuits were provided along with instruction to each judge.

\section{Statistical analysis}

Results obtained were statistically analyzed using analysis of variance technique. The difference in means was evaluated by the Duncan Multiple Range Test [16].

\section{Results and discussion}

Physical Characteristics of ginger powder incorporated biscuits

Incorporation of ginger powder at $0,2.5,5$, 7.5 and $10 \%$ level showed no difference in diameter of biscuits. The thickness of biscuits prepared from incorporation of 
ginger powder varied significantly in different treatments. Increased level of ginger powder, increased the thickness of biscuits. Mean values for the thickness of the biscuits (Table 1) showed the highest value $(1.02 \mathrm{~cm})$ in $\mathrm{T}_{4}$ while the lowest value $(0.95 \mathrm{~cm})$ in $T_{0}$ that was control. Spread factor depends on the value of the diameter and thickness of the biscuits. The highest spread factor (43.38) was observed $\mathrm{T}_{0}$ and the lowest (40.7) have been found in $\mathrm{T}_{4}$. The color was darker in biscuits having ginger powder as compared to the control. Similar effect was observed by [17-20] for different legume supplemented products. The effect of ginger powder on texture of biscuits showed that hardness and fracturability of biscuits increase with increase of ginger powder level. It was reported that addition of potato fibre reduced the firmness of dietary fiber enriched biscuits [21].

Table 1. Physical characteristics of ginger powder incorporated biscuits

\begin{tabular}{|c|c|c|c|c|c|c|}
\hline \multirow{2}{*}{ Treatments } & \multirow{2}{*}{$\begin{array}{c}\text { Width } \\
(\mathbf{c m})\end{array}$} & \multirow{2}{*}{$\begin{array}{c}\text { Thickness } \\
(\mathbf{c m})\end{array}$} & $\begin{array}{c}\text { Spread } \\
\text { factor }\end{array}$ & \multirow{2}{*}{ Color } & \multicolumn{2}{|c|}{ Texture } \\
\cline { 5 - 7 } & $4.15^{1) \mathrm{a}}$ & $0.56^{\mathrm{c}}$ & $43.38^{\mathrm{a}}$ & $169.33^{\mathrm{a}}$ & $1107.8^{\mathrm{d}}$ & $73.16^{\mathrm{e}}$ \\
\hline $\mathrm{T}_{0}$ & $4.17^{\mathrm{a}}$ & $0.98^{\mathrm{bc}}$ & $42.14^{\mathrm{abc}}$ & $162.00^{\mathrm{ab}}$ & $1099.3^{\mathrm{d}}$ & $73.42^{\mathrm{d}}$ \\
\hline $\mathrm{T}_{1}$ & $4.15^{\mathrm{a}}$ & $0.98^{\mathrm{bc}}$ & $42.34^{\mathrm{ab}}$ & $165.00^{\mathrm{ab}}$ & $1191.9^{\mathrm{c}}$ & $74.83^{\mathrm{c}}$ \\
\hline $\mathrm{T}_{2}$ & $4.15^{\mathrm{a}}$ & $0.99^{\mathrm{ab}}$ & $41.60^{\mathrm{bc}}$ & $157.33^{\mathrm{b}}$ & $1234.2^{\mathrm{b}}$ & $75.05^{\mathrm{b}}$ \\
\hline $\mathrm{T}_{3}$ & $4.14^{\mathrm{a}}$ & $1.02^{\mathrm{a}}$ & $40.70^{\mathrm{c}}$ & $160.33^{\mathrm{ab}}$ & $1352.1^{\mathrm{a}}$ & $76.16^{\mathrm{a}}$ \\
\hline $\mathrm{T}_{4}$ & & & & & \\
\hline
\end{tabular}

1) Mean of triplicate

a-d Mean scores within column followed by the same superscript are not significantly different $(\mathrm{p}<0.05)$.

$\mathrm{T}_{0}$ : Biscuits with $0 \%$ ginger powder and $100 \%$ wheat flour

$\mathrm{T}_{1}$ : Biscuits with $2.5 \%$ ginger powder and $97.5 \%$ wheat flour

$\mathrm{T}_{2}$ : Biscuits with $5 \%$ ginger powder and $95 \%$ wheat flour

$\mathrm{T}_{3}$ : Biscuits with $7.5 \%$ ginger powder and $92.5 \%$ wheat flour

$\mathrm{T}_{4}$ : Biscuits with $10 \%$ ginger powder and $90 \%$ wheat flour

\section{Chemical analysis of ginger powder} incorporated biscuits

There was an increase in the moisture content as levels of ginger powder increased up to $10 \%$ (Table 2). The moisture content is an indication of quality and stability of products. Higher moisture in ginger powder incorporated biscuits could be due to water holding capacity of powders. Protein, fibre and ash content were found to increase gradually by increasing the level of ginger powder. NFE slightly decreased in all samples when compared to the biscuits prepared only with wheat flour $\left(\mathrm{T}_{0}\right)$. The increase in protein, fat and ash contents of ginger powder incorporated biscuits could be due to the presence of them in ginger [22]. These results are similar with the previous findings of [23-24] who found that the addition of legumes increased the protein content in biscuits. Increased in protein was also found in ginger spiced maize snack [11]. It was reported that high fibre content of apple pomace reduced the moisture in the biscuits. It was also concluded that protein content of the biscuits increased by adding soybean [25]. 
Table 2. Chemical characteristics of ginger powder incorporated biscuits

\begin{tabular}{|l|l|l|l|l|l|l|l|}
\hline Treatments & Moisture & Fat & Protein & Fibre & Ash & NFE & $\begin{array}{l}\text { Caloric value } \\
\text { Kcal/100g }\end{array}$ \\
\hline $\mathrm{T}_{0}^{2)}$ & $3.50^{\mathrm{e}}$ & $20.17^{\mathrm{a}}$ & $6.99^{\mathrm{e}}$ & $0.50^{\mathrm{c}}$ & $0.86^{\mathrm{e}}$ & $67.86^{\mathrm{a}}$ & 570.84 \\
\hline $\mathrm{T}_{1}$ & $3.69^{\mathrm{d}}$ & $20.18^{\mathrm{a}}$ & $7.09^{\mathrm{d}}$ & $0.52^{\mathrm{c}}$ & $0.89^{\mathrm{d}}$ & $67.55^{\mathrm{ab}}$ & 480.18 \\
\hline $\mathrm{T}_{2}$ & $4.02^{\mathrm{c}}$ & $20.21^{\mathrm{a}}$ & $7.21^{\mathrm{c}}$ & $0.53^{\mathrm{b}}$ & $0.92^{\mathrm{c}}$ & $67.06^{\mathrm{ab}}$ & 565.32 \\
\hline $\mathrm{T}_{3}$ & $4.21^{\mathrm{b}}$ & $20.21^{\mathrm{a}}$ & $7.24^{\mathrm{b}}$ & $0.54^{\mathrm{b}}$ & $0.94^{\mathrm{b}}$ & $66.78^{\mathrm{bc}}$ & 477.97 \\
\hline $\mathrm{T}_{4}$ & $4.29^{\mathrm{a}}$ & $20.22^{\mathrm{a}}$ & $7.26^{\mathrm{a}}$ & $0.56^{\mathrm{a}}$ & $0.99^{\mathrm{a}}$ & $65.95^{\mathrm{c}}$ & 474.82 \\
\hline
\end{tabular}

${ }^{1)}$ Mean of triplicate

${ }^{\mathrm{a}-\mathrm{d}}$ Mean scores within column followed by the same superscript are not significantly different $(\mathrm{p}<0.05)$

${ }^{2)} \mathrm{T}_{0}$ : Biscuits with $0 \%$ ginger powder and $100 \%$ wheat flour

$\mathrm{T}_{1}$ : Biscuits with $2.5 \%$ ginger powder and $97.5 \%$ wheat flour

$\mathrm{T}_{2}$ : Biscuits with $5 \%$ ginger powder and $95 \%$ wheat flour

$\mathrm{T}_{3}$ : Biscuits with $7.5 \%$ ginger powder and $92.5 \%$ wheat flour

$\mathrm{T}_{4}$ : Biscuits with $10 \%$ ginger powder and $90 \%$ wheat flour

Sensory evaluation of ginger powder incorporated biscuits

The sensory evaluation scores for color, crispness, flavor, taste, texture and overall acceptability were observed to decrease with an increase in ginger powder levels when compared with biscuits produced only from wheat flour (Table 3). The color provides information about quality of raw material and baking process. It is evident from the results that the highest score was observed by biscuits prepared from $2.5 \%$ ginger powder and the lowest in biscuits prepared from 7.5 and $10 \%$. Flavor is a factor that decides the liking or disliking about the product. Incorporation of ginger powder affects the flavor of biscuits significantly and $\mathrm{T}_{2}$ (8.56) was found better as compared to others. Ginger-flavored soy-cassava biscuit prepared and reported that ginger flour improved the overall flavor of biscuits as presence of ginger reduces the beany flavor of soy bean [26]. The sensory scores for the crispiness of biscuits ranged from 5.05 to 7.64 . The highest (7.64) significant value was found for $T_{2}$ and lowest (5.05) for $\mathrm{T}_{4}$. Biscuits prepared without ginger powder got the highest (7.36) score while the lowest score was found in the biscuits prepared with $10 \%$ incorporation of ginger powder. The biscuits prepared from ginger powder indicated that supplementation significantly affected the overall acceptability of the biscuits. Biscuits with $2.5 \%$ ginger powder obtained the maximum score (8.00) while the minimum score (3.52) was achieved by the biscuits prepared from $\mathrm{T}_{4}$. The results of the present study regarding sensory properties of the biscuits are similar to the findings of $[6,27-32]$ who reported that incorporation of flaxseed flour, matri flour and cow pea flour reduce the acceptability of biscuits. 
Table 3. Sensory evaluation of ginger powder incorporated biscuits

\begin{tabular}{|c|c|c|c|c|c|c|}
\hline Treatment & Color & Crispness & Flavor & Taste & Texture & $\begin{array}{c}\text { Overall } \\
\text { acceptability }\end{array}$ \\
\hline $\mathrm{T}_{0}^{2)}$ & $7.79^{\mathrm{a}}$ & $6.78^{\mathrm{b}}$ & $7.88^{\mathrm{b}}$ & $7.51^{\mathrm{b}}$ & $7.36^{\mathrm{a}}$ & $7.10^{\mathrm{b}}$ \\
\hline $\mathrm{T}_{1}$ & $5.64^{\mathrm{d}}$ & $6.00^{\mathrm{c}}$ & $5.35^{\mathrm{c}}$ & $5.35^{\mathrm{c}}$ & $6.92^{\mathrm{b}}$ & $8.00^{\mathrm{a}}$ \\
\hline $\mathrm{T}_{2}$ & $7.67^{\mathrm{b}}$ & $7.64^{\mathrm{a}}$ & $8.56^{\mathrm{a}}$ & $8.14^{\mathrm{a}}$ & $6.06^{\mathrm{c}}$ & $5.72^{\mathrm{c}}$ \\
\hline $\mathrm{T}_{3}$ & $6.06^{\mathrm{c}}$ & $5.66^{\mathrm{d}}$ & $4.13^{\mathrm{d}}$ & $5.00^{\mathrm{d}}$ & $5.57^{\mathrm{d}}$ & $4.21^{\mathrm{d}}$ \\
\hline $\mathrm{T}_{4}$ & $5.64^{\mathrm{d}}$ & $5.05^{\mathrm{e}}$ & $3.29^{\mathrm{e}}$ & $3.56^{\mathrm{e}}$ & $4.92^{\mathrm{e}}$ & $3.52^{\mathrm{c}}$ \\
\hline
\end{tabular}

${ }^{1)}$ Mean of triplicate

${ }^{\mathrm{a}-\mathrm{d}}$ Mean scores within column followed by the same superscript are not significantly different $(\mathrm{p}<0.05)$

2) $\mathrm{T}_{0}$ : Biscuits with $0 \%$ ginger powder and $100 \%$ wheat flour

$\mathrm{T}_{1}$ : Biscuits with $2.5 \%$ ginger powder and $97.5 \%$ wheat flour

$\mathrm{T}_{2}$ : Biscuits with $5 \%$ ginger powder and $95 \%$ wheat flour

$\mathrm{T}_{3}$ : Biscuits with $7.5 \%$ ginger powder and $92.5 \%$ wheat flour

$\mathrm{T}_{4}$ : Biscuits with $10 \%$ ginger powder and $90 \%$ wheat flour

\section{Conclusion}

It was concluded that ginger powder increased the protein, ash and fibre content while decreased the NFE content. These results can be used to improve the nutritional value of food by adding ginger powder. However, in organoleptic evaluation, ginger powder incorporated biscuits were not much liked by the panel. It is suggested that consumer education and public enlightenment on the nutritional benefits of ginger can encourage acceptability of ginger powder incorporated biscuits.

\section{Authors' contributions}

Conceived and designed the experiments: $\mathrm{T}$ Kausar \& M Asjad, Performed the experiments: Muhammad Asjad, Analyzed the data: $T$ Kausar \& $M$ Nadeem, Contributed materials/ analysis/ tools: T Kausar, M Asjad \& M Nadeem, Wrote the paper: T Kausar.

\section{References}

1. Aslam M, Gailani AH \& Qazi AR (1982).

Some dimensions of rural food poverty with special emphasis on nutritional status and its improvent. Final report German agro actin project. University of Agriculture, Faisalabad, Pakistan P. 79.
2. Castro RF, Garcia MC\& Marina ML (2007). Determination of soybean proteins in soybean-wheat and soybeanrice commercial products by perfusion reverse based high performance liquid chromatography. J Food Chem 100(3): 948-955.

3. Gandhi AN, Kotwaliwale J, Kawalkar D, Srivastava V, Parihar P\& Raghu N (2001). Effect of incorporatin of defatted soy flour on the quality of sweet biscuits. J Food Sci Technol 38: 502-503.

4. Sudha M, Vetrimani R \& Leelavathi K (2007). Influence of fiber from different cereals on the rheological characteristics of wheat flour dough and on biscuit quality. Food Chem 100: 1365-1370.

5. Ogunjobi MAK \& Ogunwolu SO (2010). Physicochemical and sensory properties of cassava flour biscuits supplemented with cashew apple powder. J Food Tech 8(1): 24-29.

6. Hussein AMS, El-Azeem AS, Hegazy AM, Afifi AA \& Ragab GH (2011). Physicochemcial, sensory and nutritional properties of corn-fenugreek flour composite biscuits. Australian $J$ Basic and Appl Sci 5(4): 84-95. 
7. Nassar AG, AbdEl-Hamied AA \& ElNaggar EA (2008). Effect of citrus byproducts flour incorporation on chemical, rheological and organoleptic characteristics of biscuits. World $J$ Agric Sci 4(5): 612-616.

8. Aziah NAA, Mohamad NAY \& Ho LH (2012). Physicochemical and organoleptic properties of cookies incorporated with legume flour. Inter Food Res J 19(4): 1539-1543.

9. Kohajdova Z, Karovicova J \& Magala M (2013). Rheological and qualitative characteristics of pea flour incorporated cracker biscuits. Croat J Food Sci Technol 5(1): 11-17.

10. Tapsell LC, Hemphill I, Cobiac L, Patch CS, Sullivan DR, Fenech M, Roodenrys S, Keogh JB, Clifton PM, Williams PG, Fazio VA \& Inge KE (2006). Health benefits of herbs and spices: the past, the present, the future. Med J Aust 185(4):4-24.

11. Sade FO \& Aderonke AO (2013). Physicochemical properties, vitamins, antioxidant activities and amino acid composition of ginger spiced maize snack 'kokoro' enriched with soy flour (a Nigeria based snack). Agri Sciences 4(5B): 73-77.

12. AACC (2000). Approved Methods of American Association of Cereal Chemists. The American Association of Cereal Chemists, Inc. St. Paul. Minnestoa, USA.

13. AOAC (2000). Official Methods of Analysis, $15^{\text {th }}$ Edition. Association of Official Analytical Chemists. Washington DC. USA.

14. Paul AA \& Southgate DA (1979). "The composition of Foods." $4^{\text {th }}$ Edition, Elsevier North, Holland Biomedical Press, Amestrdam.

15. Larmond E (1980). Laboratory methods of sensory evaluation of food. Research
Branch Canada. Dept. Agric. Publications.

16. Steel RGD, Torrie JH \& Dickey D (1997). Principles and procedures of Statistics. A biometrical approach. $3^{\text {rd }}$ Ed. McGraw Hills Book Co. Inc New York.

17. Hallen E, Iganoglu S \& Ainsworth $P$ (2004). Effect of fermented-germinated cowpea flour addition on the rheological and baking properties of wheat flour. J Food Eng 63(2): 177184.

18. Mohammed I, Ahmed AR \& Senge B (2012). Dough rheology and bread quality of wheat-chickpea flour blend. Indus Crop Prod 36(1): 196-202.

19. Abou-Zaid AAM, Ramadan MT \& AlAsklany SA (2011). Utilization of faba bean and cowpea flours in gluten free cake production. Aust J Basic Appl Sci 5(12); 2665-2672.

20. Tiwari BK, Brennan CS, Jaganmohan R, Surabi A \& Alagusundaram K (2011). Utilization of pigeon pea (Cajanus cajan L) by-products in biscuit manufacture. LWT-Food Sci Technol 44(6): 1533-1537.

21. Brennan CS \& Samyue E (2004). Evaluation of starch degradation and textural characteristics of dietary fiber enriched biscuits. Int J Food Properties 7: 647-657.

22. Farell KT (1985). Spices, condiments and Seasonings. $2^{\text {nd }}$ Edition. Aspen Publicaiton, Maryland. Pp.15-253.

23. Eissa HA, Hussain AS \& Mostafa BE (2007). Rheological properties and quality evaluation of Egyptian balady bread and biscuits supplemented with flours of ungerminated and germinated legume seeds or mushroom. Pol J Food Nutr Sci 57:487-496.

24. Hooda S \& Jood S (2003). Effect of soaking and germination on nutrient and 
antinutrient content of fenugreek. $J$ Food Biochem 27: 165-176.

25. Singh A, Rana I, Sahi NC, Lohani UC \& Chand K (2012). Optimization of process variables for preparation of apple pomace-black soyflour based biscuits. Int J Food Agri Vet Sci 2(1): 101-106.

26. Akinwande BA, Ade-Omowaye BIO, Olaniyan SA \& Akintaro OO (2008). Quality evaluation of ginger-flavoured soy-cassava biscuit. Nutrition \& Food Sci 38(5): 473-481.

27. Gambus H, Mikulec A \& Matusz A (2003). The Canadian muffins and hermit cookies with linseeds. Zywnosc 10 (3): 82-92.

28. Iqbal MA (1997). Quality aspects of biscuits containing fig in their formulation. M.Sc Thesis. Dept. Food Tech. Univ. Agric. Faisalabad. Pakistan.
29. Shearer AEH (2002). Physicochemical properties of muffins prepared with various levels of flaxseed flour. Animal and Food Sciences. Univ. Delaware College of Agric. Newark.

30. Alpers L \& Sawyer-Morse M (1996). Eating quality of banana nut muffins and oatmeal cookies made with ground flaxseed. J Am Diet Assoc 96(8): 794796.

31. Sharma S, Bajwa U\& Nagi HPS. (1999). Rheological and baking properties of cowpea and wheat flour blends. $J \mathrm{Sci}$ Food Agric 79(5):657-662.

32. Ullah HE (1990). Effect of supplementation of matri (Lathrys sativus) on the quality of biscuits. M.Sc Thesis. Dept. Food Tech. Univ. Agric. Faisalabad. Pakistan. 